\title{
Synergy Development of "State-Representative Apparatus" in Accelerating Social Forestry Policy Outcomes in Ngawi Regency, East Java
}

\author{
$\triangle 1,2$ Arsad Ragandhi \\ ${ }^{1}$ Leadership and Policy Innovation Program, The Graduate School, \\ Universitas Gadjah Mada, Indonesia \\ ${ }^{2}$ Ngawi Regency Government \\ DOI: $10.32781 /$ cakrawala.v15i2.374
}

\begin{tabular}{l|l}
\hline ARTICLE INFO & $\begin{array}{l}\text { Abstract: } \\
\text { Social forestry is a new approach to solving problems around forests, such as } \\
\text { Community Forestry, } \\
\text { MoU, } \\
\text { Social Forestry, } \\
\text { Stakeholder, } \\
\text { Synergy. }\end{array}$ \\
\hline $\begin{array}{l}\text { Article History: } \\
\text { regarding their involvement in forest management. However, local communities } \\
\text { cannot stand alone in their implementation but must collaborate with other } \\
\text { relevant stakeholders. A qualitative descriptive approach is used in this paper } \\
\text { to capture efforts to build synergies between stakeholders in forest management } \\
\text { and empowerment of forest communities in Ngawi Regency and identify } \\
\text { opportunities and challenges afterward. The results of our analysis found that } \\
\text { Accepted : Nov 3,2021 } \\
\text { Publish : Dec 21, 2021 } \\
\text { social forestry policy outcomes. The dichotomy between "forest" and "social" } \\
\text { affairs is increasingly visible in the division of tasks of each stakeholder involved. } \\
\text { There is a need for clear legal rules regarding the roles and limits of allowable } \\
\text { intervention for Regency governments. In addition, an urgent issue that needs to } \\
\text { be addressed is the acceleration of capacity building and the capability of local } \\
\text { communities, which are identified as essential factors in the success of social } \\
\text { forestry policies. }\end{array}$ \\
\hline
\end{tabular}

\section{INTRODUCTION}

Policy dynamics in forestry sector management have evolved. Several approaches, both theoretical and practical, have been proposed, developed, and implemented. They started from a centralized forest management approach by the state, industrial forestry, to the current trend through community forestry, which has been tried in various parts of the world and is growing massively in most third world countries (Gilmour, 2016). Community forestry or social forestry policies emphasize devolution and a higher degree of community involvement in forest management (Adiwibowo et al., 2013). Maryudi et al. (2012), mentioned that community forestry is very much connected to the following three objectives: 1) alleviating the poverty of forest users, 2) empowering them, and 3) improving the condition of the forests. However, various studies conducted by several researchers such as Vermeulen et al. (2008); Dressler et al. (2010); Maryudi \& Krott (2012); Schusser et al. (2013); Arts \& de Koning (2017) found different conclusions in the effectiveness of achieving results from community forestry policies.

\footnotetext{
${ }^{\square}$ Corresponding author :

Address : Bulaksumur, Caturtunggal, Kec. Depok, Kabupaten Sleman, DIY 55281

Email : arsadragandhi@gmail.com
}

Hal. 109-123

p-ISSN 1978-0354 | e-ISSN 2622-013X 
The difference in achieving community forestry policy outcomes strongly indicated that the implementation of community forestry should not be one size fits all (Gelo \& Koch, 2012). The opinion that this policy can become a panacea for various problems identified has not been proven true because the preferences and perceptions of most resource users are not always the same (Ostrom et al., 2007). Several factors that influence policy include whom the actors are involved in, how the policy environment, and how the policies are interconnected and interrelated (Dunn, 2003). Attention to the actors or stakeholders involved is an essential emphasis. The administrative paradigm shift from Old Public Administration to New Public Administration (Osborne \& Gaebler, 1993) brought a shift from the government (classical regulation with strong state authority in policy formulation and implementation) to governance (current regulation, with an emphasis on empowering people and private sector actors in sharing power with the state) ultimately affects the policy cycle, especially in the policymaking process (Krott, 2008; Lo, 2018).

One practice interpretation of forest governance is forest management decentralization (Arts, 2014). Decentralization is a dynamic process in which actors at each level of government interact and find the appropriate balance among the authorities responsible for forests (Barr et al., 2006). Decentralization in the political process is designed to reorganize or disperse functions, powers, human and financial resources to the lower level (Sahide et al., 2016). In other words, the policy-making process is closer to the object of the policy, then a problem at the site level can be identified, and problem-solving is given accurately. Decentralization is expected to create a better system of government since it is improving the quality and the effectiveness of the government system; overall, including transparency, accountability also increasing the authority and capacity of a region (Wulandari et al., 2019).

In Indonesia, decentralization emerged along with the changes in sociopolitical conditions after the collapse of the New Order hegemony. The Reform Order brought the spirit of decentralization and autonomy to devolve most government affairs (except defense and security affairs, fiscal and monetary affairs, foreign affairs, judicature, religion, and other policies in strategic areas such as technologies, conservation, and national standardization) are decentralized to the Regency (Nurrochmat et al., 2021). The decentralization of forestry sector is also influenced by the laws governing the division of authority between the center and regions. In the Regional Autonomy Law 22/1999, the Regency governments were given authority to issue small-scale timber extraction and forest conversion permits. Contradictory, Law 41/1999 on forestry and Law 32/2004 on regional autonomy as a continuation for Law 22/1999 in outlining the division of administrative authority in the forestry sector under regional autonomy, designed to restrict the authority of Regency and provincial governments and to reaffirm the dominant role played by the Ministry of Forestry in Jakarta (Maryudi, 2012). The phenomenon of re-centralization has strengthened with the emergence of Law 23/2014, which revoked all Regency government authorities in the forestry sector except for the management of the Grand Forest Park (Taman Hutan Raya) (Pribadi et al., 2020). The existing Regional Governance Law has shifted almost all authorities in forest management from the regency to the province. Moreover, associated with the newly established Law 11/2020 on job creation, The Government of Indonesia introduces a single multipurpose forest 
utilization license, including agroforestry which further strengthened the impression of re-centralization of the forestry sector (Nurrochmat et al., 2021).

Various dynamics in Indonesia's changing political situation, policy, and politics in forest management also bring changes to any actors involved (Prabowo et al., 2016; 2017). The constellation of actors is also suspected to be one of the factors that influence the success of forest management itself. Actors can be divided into several sides, such as government actors, private actors, and local communities. In the latest developments in social forestry policies, attention to actors from the government side is considered vital since they have different preferences and interests (Krott, 2005; Krott \& Hasanagas, 2006). Bureaucracies have dualistic goals: 1) to provide public services with a problem-oriented delivery approach, as stated in their formal mandates; and 2) to pursue the organizational interests of survival and expansion (Giessen et al., 2014). These actors compete for power in the form of formal mandates to pursue policies in these emerging issue areas and to acquire staff and budgets (Wibowo \& Giessen, 2015).

The synergy among actors is expected to accelerate the achievement of outcomes of social forestry policies. Therefore, this paper aims to describe efforts to develop synergies among actors from the government and identify opportunities and challenges in implementing social forestry policies in Ngawi Regency, East Java, after signing a Memorandum of Understanding by several government actors involved in implementing social forestry policies at the site level.

\section{THEORETICAL FRAMEWORK}

The emergence of a public policy is used to overcome public problems that have not been found a solution. Dunn (2003) defines public policy as a complex pattern of interdependent collective choices. These options are intended to address the problem and to accommodate all the interests of the stakeholders involved. However, almost no policy can satisfy all parties involved, so the gap between the existing interests will always cause conflict.

In the context of natural resource management, forestry policies cannot be split from a public policy perspective. Cubbage et al. (1993) define forest policy as an objective directive supporting or hindering an action responding to forest use and management problems. Forestry policy is a social bargaining process that regulates conflicts of interest in the use and protection of forests according to forestry sector programs (Krott, 2005). In this social bargaining process, a policy is distinguished from the conflict resolution efforts of individual stakeholders, and policy-making processes must be defined as actions taken by the community as a whole. Furthermore, interests in forestry policies are based on an action orientation, which is adhered to by individuals or groups designed to obtain benefits from forest resources (Krott, 2005). The policy process in managing forest resources cannot be separated from the political process that accompanies it.

There has been a paradigm shift in forest management from state-based forest management to community-based forest management. The state-based forest management paradigm has failed to channel forest resource benefits to communities (Ojha et al., 2014; Barrow et al., 2016). The forest management paradigm that considers forests an essential source of economic income for the country's development based on timber forest products has resulted in forest management being more inclined towards industrialism and capitalism (Kusdamayanti, 2008). The forestry approach going on for quite a long time does not guarantee socio-economic benefits 
for forest communities also the sustainable use for the forest itself (Fisher et al., 2019). Of course, various problems that occur in the management of forest resources cannot be solved by one party or one particular actor. Differences in interests and potential conflicts must be resolved through a collaboration mechanism between actors, defined as good forest governance (Cashore and Stone, 2012).

\section{RESEARCH METHODOLOGY}

This research was conducted in Ngawi regency, especially in Ngawi's Forest Management Unit (KPH Ngawi), East Java. There are 95 villages directly adjacent to or around forest areas out of 217 villages in the Ngawi Regency. In the KPH Ngawi area, there are $69 \mathrm{LMDH}$, and all of them have applied for forest resources management permits through forestry partnership scheme or well known as Kulin KK. There are 37 out of the $69 \mathrm{LMDH}$ (as of April 30th, 2021) who have obtained permits for forest resources management through the Minister of Environment and Forestry Decree on Kulin KK issued.

This research was conducted from January 2021 to July 2021 to capture the phenomenon of implementing social forestry policies, which is focused on the relationship between stakeholders involved in regulating their respective roles and functions and their efforts to build synergies using a descriptive qualitative approach. Primary data collection was carried out by observations and semi-structured interviews with various participants involved in policy implementation. The secondary data are legal regulations, cooperation agreement texts, and field reports related to program implementation, and they are analyzed and synthesized using content analysis.

\section{RESULT AND DISCUSSION}

An overview of social forestry policy implementation in Ngawi Regency

Whose actors involved in forest regulation and management from time to time continue to have dynamics referring to the political, policy, and polity situation that occurs. Similarly, at the site level, Ngawi Regency, $35 \%$ of its area is designated as state forest, has historically implemented various legal regulations and policies related to forest management. The historical background states that forest management in Ngawi Regency for several decades cannot be separated from the central role and domination of Perhutani. The decentralization phenomenon after the reform did not seem to provide any change in forest management in Ngawi in particular and Java in general. The euphoria of decentralization can only be felt and utilized by regency governments outside Java, but not for regency governments inside Java because of the layering in the laws and regulations, governing who has the right to regulate forest governance in Java (Erbaugh \& Nurrochmat, 2019; Nurfatriani et al., 2015). Perhutani historically has had a powerful position. Later, it was strengthened again through the issuance of Government Regulation PP.72/2010. Confirms the continuation of Perhutani as a government-owned enterprise that is assigned the task of managing forests in state forests located in Central Java Province, East Java Province, West Java Province, and Banten Province, except for conservation forests, based on the principles of sustainable forest management and good corporate governance principles. 
The emergence of new laws and regulations related to forest management through Ministerial Decrees P.83/2016 and P.39/2017 seems to place Perhutani uncomfortable (Suharjito, 2018). This regulation gives local communities a higher legal basis and more secure tenure through partnership permits and 35 years of forest management time. The benefits that local communities will receive more or less reduced and threatened the interests of Perhutani in the dominance of forest management (primarily through P.39/2017, which gives a more significant role and percentage of profits to the community).

The euphoria of implementing social forestry in Ngawi can be an example of how the dominant actor (Perhutani) tries to maintain power through various methods and sources of power (Setiahadi et al., 2017; Ragandhi et al., 2021). In its development, 69 LMDHs (Lembaga Masyarakat Desa Hutan) in Ngawi Regency are "unified" to apply for a forestry partnership permit scheme (Pengakuan dan Perlindungan Kemitraan Kehutanan). 37 LMDHs have obtained the partnership permit (SK KulinKK), and the rest are still in the technical and administrative verification stage. In this condition, Perhutani becomes the most benefited party. With the "cohesiveness" of local communities in choosing a partnership scheme, Perhutani will be able to maintain their authority, especially in terms of forest governance planning and greater profit sharing.

\section{Signing Memorandum of Understanding: Affirmation of the Fragmentation of "Forest" and "Social" Affairs}

The massive development of the implementation of Social Forestry policies in Ngawi, as aforementioned, on the other hand, has attracted the attention of the central government. The Ministry of Ecology and Forestry (MoEF), through the Center for Social Forestry and Environmental Partnership for Java, Bali, and Nusa Tenggara region (Balai Perhutanan Sosial dan Kemitraan Lingkungan wilayah Jawa, Bali dan Nusa Tenggara, later called: BPSKL Jabalnusra), intervened by providing various training and assistance to encourage the establishment of Kelompok Usaha Perhutanan Sosial (KUPS) as a follow-up to the issuance of the partnership permit. It is hoped that local communities can benefit from both on-farm and off-farm activities to get value-added forest products and institutional capacity building.

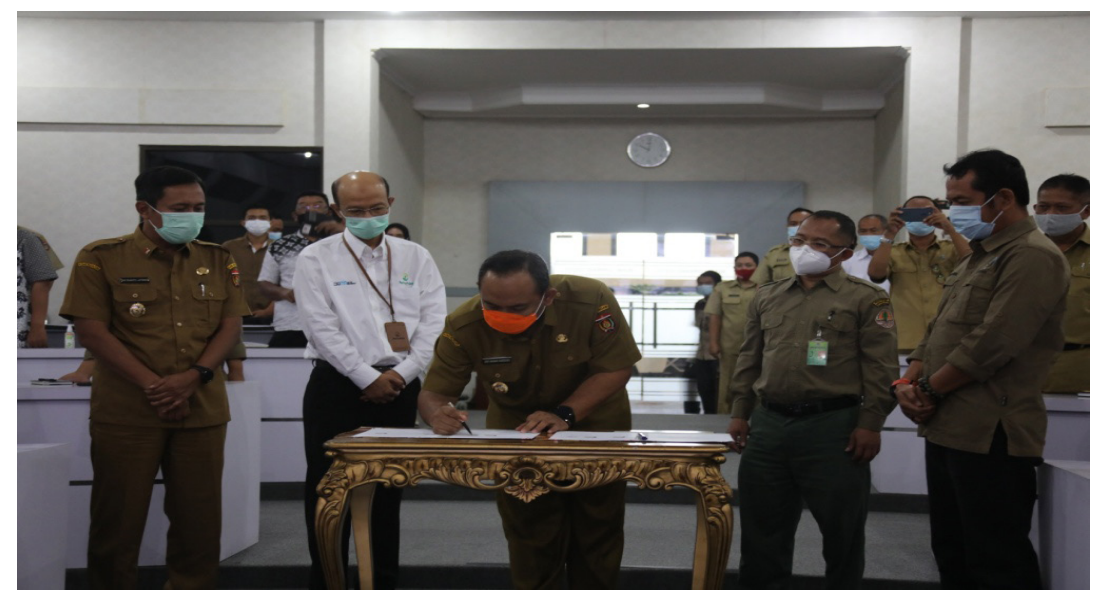

Source : Bagian Humas dan Protokol Kab. Ngawi

Figure 1

The signing of the Memorandum of Understanding by the Regent of Ngawi 
The social forestry policy, which was proclaimed as a national strategic program, also attracted the involvement of cross-ministerial ministries to support the implementation of the program. For example, the Ministry of Villages, Development of Disadvantaged Areas, and Transmigration explicitly supports the implementation of Social Forestry through Ministerial decree Number 13/2020 concerning Priority for the use of Village Funds in 2021. Through this regulation, village Funds can be used for productive economic development, product, and regional development excellence related to the forestry sector. In line with the decree above, the Ministry of Home Affairs encourages the involvement of Regional Governments in the implementation of Social Forestry through the Letter of the Minister of Home Affairs to all governors (except Daerah Khusus Ibukota Jakarta) Number 552/1391/SI and Regents/Mayors Number 552/1392/SI dated February 13, 2020, regarding support development of social forestry enterprises. The Government of Indonesia has recently encouraged the acceleration of the implementation of social forestry through Government Regulation No. 23/2021 concerning Forestry Implementation, as the implementation of the provisions of Article 36 and Article 185 letter b of Law Number 11 of 2020 concerning Job Creation.

From the above regulations, in general, it can be concluded that local governments (especially regency governments) in the implementation of social forestry policies are expected to have a role and involvement again. Local government involvement is encouraged to build institutional capacity and productive economic development, which is expected to directly impact the community's poverty level (Pribadi et al., 2020). However, interviews with the Ngawi Regent and the Head of the Office related to this issue gave the impression that the Ngawi Regency government is still reviewing the regulations related to this social forestry policy. Based on Law 23/2014,

Table 1. The Task and Obligation of Actors Involved

\begin{tabular}{|c|c|c|}
\hline Actors Involved & Task & Obligation \\
\hline $\begin{array}{l}\text { Ngawi Regency } \\
\text { Government }\end{array}$ & $\begin{array}{l}\text { Support the development of social } \\
\text { forestry business as executor of gov- } \\
\text { ernment affairs in Ngawi Regency. }\end{array}$ & \multirow{3}{*}{$\begin{array}{l}\text { together to prepare a synergy work } \\
\text { plan for social forestry business } \\
\text { development in Ngawi Regency, } \\
\text { aligned with the forest manage- } \\
\text { ment plan of Perum Perhutani East } \\
\text { Java Regional Division and related } \\
\text { area stakeholders; } \\
\text { implement synergy following the } \\
\text { terms of reference for activities } \\
\text { that have been agreed upon by the } \\
\text { parties; } \\
\text { provide human resource support } \\
\text { and technical support needed in the } \\
\text { implementation of the social for- } \\
\text { estry program in Ngawi Regency; } \\
\text { together compile a report on the } \\
\text { implementation of the synergy } \\
\text { every } 6 \text { (six) months. }\end{array}$} \\
\hline $\begin{array}{l}\text { BPSKL Jabal- } \\
\text { nusra }\end{array}$ & $\begin{array}{l}\text { Support the development of social } \\
\text { forestry business in Ngawi Regency } \\
\text { in its capacity as a policy implementer } \\
\text { to increase community participation } \\
\text { in forest management, customary for- } \\
\text { est management, and environmental } \\
\text { partnerships in Java, Bali, and Nusa } \\
\text { Tenggara regions. }\end{array}$ & \\
\hline $\begin{array}{l}\text { Perhutani Divre } \\
\text { Jatim }\end{array}$ & $\begin{array}{l}\text { Support the development of social } \\
\text { forestry business in Ngawi Regency } \\
\text { in its capacity as a forest manager } \\
\text { in state forest located in East Java } \\
\text { Province, except conservation forest, } \\
\text { based on sustainable forest manage- } \\
\text { ment principles and good corporate } \\
\text { governance principles }\end{array}$ & \\
\hline
\end{tabular}

Source: Data Processed, 2021 
Regency/City Governments no longer have the authority to manage and regulate forest areas. However, several recent regulations encourage local government interventions that will indirectly intersect the forest area regulation, especially the development of activities within the forest. Suppose this is not synchronized with the Provincial Forestry Service (as the government authority mandated in forestry regulation) and Perhutani (as the State-Owned Enterprise manages Java's forests). In that case, it will pose a risk to the regency government if there is no legal basis for them to intervene in the social forestry program. Based on that condition, BPSKL Jabalnusra and Lembaga Swadaya Masyarakat PALAPA (as the Social Forestry Assistance NGO in Ngawi Regency) encouraged a Memorandum of Understanding among the relevant parties, especially between the Ngawi Regency Government and Perhutani that can be the basis of synchronization for the parties in the division of tasks and program intervention authority to accelerate the achievement of social forestry outcomes.

The signing of the Memorandum of Understanding among the three related parties: the Ngawi Regency Government, Perhutani of East Java Regional Division, and BPSKL Jabalnusra, finally materialized and was held on April 27, 2021, at the Ngawi Regency Command Center Building. This event was held by signing a Memorandum of Understanding, handing over the SK KulinKK to LMDH representatives, and productive economic tools assistance in chopping and organic fertilizer processors machines for four "pilot projects" LMDH. According to Ojom Somantri as the head of BPSKL Jabalnusra, this Memorandum of Understanding is the first to be signed by the parties concerned. Therefore, it can be a new milestone in the history of the implementation of Social Forestry in Java. The Ngawi Regency Government, represented by the Ngawi Regent Ony Anwar, hoped that with this Memorandum of Understanding, synchronization among parties, especially between the Regency Government and Perhutani, could occur be further improved. The Regency Government recognizes and supports Perhutani as a regulator in forestry affairs that handles ecological problems of forest sustainability. In contrast, the local government will try to support the program's implementation, especially to achieve social and economic outcomes (Figure 1).

The Social Forestry Program, in general, is in synergy with the vision and mission of Ngawi Regency 2021-2026, namely "the realization of an independent, moral, prosperous and competitive Ngawi Regency community based on agropolitan in the spirit of gotong royong within the framework of the Republic of Indonesia". The GRDP structure of Ngawi Regency in 2020 is also dominated by income from the agronomics sector, where around 35.33\% of GRDP is contributed by the agriculture, forestry, and fishery sectors (BPS, 2021). Meanwhile, BPSKL Jabalnusra, as an extension of the Ministry of Environment and Forestry, is responsible for spurring increased community participation in social forestry efforts through institutional capacity building and productive economic assistance to social forestry business groups. Perhutani itself is the party that will focus on production and conservation matters. In other words, Perhutani will focus on "forestry" issues. At the same time, "social and economic" affairs will be further developed with the role of the regency government, the Provincial Forestry Service, and BPSKL Jabalnusra.

With this Memorandum of Understanding, it is hoped that it will become the initial basis so that there is no tug-ofwar in authority to regulate and manage forests and the obligation to empower communities around forests. In the poverty 
alleviation program for communities around the forest, the Regency government will also get legal standing certainty, thus avoiding mal-administration and friction with other actors involved. Although the boundaries of duties and authority between one actor and another still seem gray. However, it can be seen phenomenon that this Memorandum of Understanding has drawn a line between "forestry" affairs and "social" affairs, which each actor will handle as an actor representing the government in implementing this social forestry policy (Table 1).

Identification of Opportunities and Challenges After the Memorandum of Understanding

As stated above in the background session and description of the Memorandum of Understanding, the next big question is the opportunities and challenges after signing the Memorandum of Understanding. Ngawi Regency, in regional stability, is a regency that tends to be "cool" in the various political contestations that occur. Politically, Ngawi Regency is the basis of the Indonesian Democratic Party of Struggle (PDI-P), evidenced by the acquisition of 20 seats out of 45 seats in the Ngawi regional parliament (DPRD). In the 2019 presidential election, Jokowi also received a majority vote from the Ngawi population, with a total vote of $78.01 \%$. Meanwhile, in the contestation for the Ngawi Regent's election, which took place at the end of last year, the candidate pair Ony Anwar Harsono and Dwi Rianto Jatmiko earned $94.42 \%$ of the votes. From the three examples of political contestation results above, it can be concluded that the political conditions in Ngawi tend to be cohesive and stable because most people's votes are affiliated with certain political groups. The community's social conditions also tend to be calm and conducive without any significant social conflicts that appear on the surface. This condition significantly supports the implementation of social forestry programs that occur at the site level. Conflicts that occurred in selecting schemes and implementing social forestry policies in other areas did not occur in Ngawi. In addition to other factors that underlie people's choices in social forestry schemes, this conducive political factor is important in efforts to create community conduciveness (Ragandhi et al., 2021). The selection of a partnership scheme provides more conduciveness than the IPHPS scheme, which in practice causes more conflicts among the parties involved (Suharjito, 2018; Agusti et al., 2019; Ramadhan et al., 2021).

For decades, there was a perception that the forestland was gazetted during Dutch colonial as "permanent forest estates", which was distinguished from agricultural land of private ownership (Peluso, 2011). Based on this assumption, Heri Sujianto as social forestry assistant from the LSM PALAPA, revealed that there had been a dichotomy between forest farmers and land farmers so far. For example, the agriculture office (Dinas Pertanian) does not dare to include forest farmers in the list of recipients of subsidized fertilizers. Because the legality of forest community institution (LMDH) or forest farmer group (KTH) has not yet been recognized, they cannot be included in the Definitive Plan for Group Needs (RDKK) recipients of subsidized fertilizers. With a Memorandum of Understanding between Perhutani and the Regency government, it is hoped that it will recognize forest farmers to have the same rights as land farmers. In this case, forest farmers have obtained recognition through the partnership permits (SK KulinKK) from the MoEF. This permit decree includes certainty "by name" and "by address" who manages the land and 
how large the land is. There is no longer reason for the agriculture office to exclude them from subsidized fertilizer or other agricultural-related assistance.

Later, there is an opportunity for other agencies within the regency government, such as the Cooperatives and UMKM Office (Dinas Koperasi dan UMKM) and the Trade and Markets Office (Dinas Perdagangan dan Pasar), to provide soft loan assistance. They were assisting in packaging, promoting, and marketing social forestry products to increase the income of forest farmers. The Community Empowerment Service and Village Government (Dinas Pemberdayaan Masyarakat dan Pemerintahan Desa) are also expected to instruct the headman (Kepala Desa) to use a part of village funds for social forestry businesses. So far, no village funds have been used to strengthen local community institutional capacity or develop social forestry businesses. The headman still does not understand the related rules, and village funds are widely used for village infrastructure development (Wahyudi \& Wicaksono, 2020).

In addition, several challenges were identified in the implementation of social forestry policies in Ngawi. Policy internalization is an absolute requirement that the Perhutaniapparatus mustunderstand at the managerial and site levels. Perhutani officials at the managerial level have been open and supportive of the dynamics of the policy. One example of supporting the internalization of social forestry programs is the establishment of a social forestry directorate within Perhutani. This must be followed up with policy internalization for apparatus at the site level. The initial identification found that the apparatus at the site level was still not wholly willing to change from the old pattern to the new policy pattern. It is alleged that there is still some low grading or abuse of power at the site level. One example is the practice of land renting, illegal levies to local communities, and profit-sharing that is not provided following the agreement (Setiahadi, 2012; Djamhuri, 2012; Pratama, 2019).

The next big homework is how to increase the rights and access granted to local communities also goes hand in hand with increasing community capabilities. Chambers (1995) mentioned that a decent life for the poor could be improved and maintained in three ways, including through increasing their livelihood capabilities, through tangible assets (in the form of storage and the resources they have), and through intangible assets (in the form of claims and access to available resources). When local communities own intangible and tangible assets by granting of partnership permits, the next step is to build community capabilities to survive the deprivation trap (Chambers, 1995; Royce, 2018).

For decades forest farmers have been accustomed to agroforestry cropping patterns on bare land or when stands of staple crops have not yet shaded their agroforestry crops. Then usually, when the staple crops have formed shade, they will be obliged to move from the land they cultivate (Sunderlin, 1997). After the partnership permit is issued, they have the right to manage the land for 35 years, so their nomadic habit must be abandoned and replaced with land optimization with the technique of planting land under trees stand (PLDT) (Yokota et al., 2014; Morhart et al., 2014; Banowati \& Prajanti, 2017). This change in cropping patterns and habits is currently not owned by forest farmers. Consequently, further assistance is needed from the forestry service extension so that forest farmers have skills in PLDT. This extension is also still a problem because the span of management is too far. The extension workers are structurally located at the provincial level. In quantity, the number of extension workers is also limited, so mentoring and counseling 
farmers is less than optimal (Galudra, 2019). The adequate number of extension workers is expected to be increased as a follow-up to the implementation of this program. Bureaucratizing non-government organizations as governmental forest extension services can also be an option because NGOs possess strengths as agents of community development programs with technical and organizational expertise and experience in mobilizing communities (Rahayu et al., 2020).

\section{CONCLUSION}

Contestation over forest management rights is a severe challenge for successfully implementing social forestry policy (Fisher et al., 2018). This challenge is usually caused by differences in stakeholders' understandings and interests in social forestry, leading to conflicts and tensions (Setiahadi et al., 2017). The presence of this Memorandum of Understanding is expected to be the initial capital for accelerating the achievement of social forestry outcomes in Ngawi by building synergy from various actors involved, especially actors from the government side. Commitment from the parties involved is needed to maximize the opportunities and overcome the challenges outlined above. At present, there is an asymmetry between resources dedicated to approving social forestry permits and their implementation versus capacity building, monitoring, and evaluating management outcomes (Erbaugh, 2019). Strengthening the capacity and capability of local communities is an important thing to do. The local government plays a significant role in establishing this focal point (Pribadi et al., 2020). Local communities who have the capability will increase their bargaining position against each Perhutani policy and reduce the perception gap between the local community and Perhutani (Setiahadi et al., 2017). For regulatory instruments, there are contradictions among several rules and regulations as well as regulations that are no longer relevant (Nurfatriani et al., 2015). Legal certainty is needed to provide convenience for the parties involved in taking follow-up programs related to implementing social forestry policy.

\section{REFERENCES}

Adiwibowo, S., Shohibuddin, M., \& Kartodiharjo, H. (2013). Kontestasi Devolusi : Ekologi Politik Pengelolaan Hutan Berbasis Masyarakat. In H. Kartodiharjo (Ed.), Kembali ke jalan lurus: kritik penggunaan ilmu dan praktek kehutanan Indonesia (pp. 255-307).

Agusti, T. M., Nurjaya, I. N., \& Koeswahyono, I. (2019). Implementasi regulasi perhutanan sosial yang bermanfaat bagi masyarakat sekitar hutan. Jurnal Ilmiah Pendidikan Pancasila Dan Kewarganegaraan, 4(2), 300-309. Retrieved from http://journal2. um.ac.id/index.php/jppk

Arts, B. (2014). Assessing forest governance from a 'Triple G' perspective: Government, governance, governmentality. Forest Policy and Economics, 49, 17-22. https://doi.org/10.1016/j. forpol.2014.05.008

Arts, B., \& de Koning, J. (2017). Community Forest Management: An Assessment and Explanation of its Performance Through QCA. World Development, 96, 315325. https://doi.org/10.1016/j. worlddev.2017.03.014 
Banowati, E., \& Prajanti, S. D. W. (2017). Developing the under stand cropping system (PLDT) for sustainable livelihood. Management of Environmental Quality: An International Journal, 28(5), 769-782. https://doi. org/10.1108/MEQ-08-2015-0163

Barr, C. M., Resosudarmo, I. A. P., Dermawan, A., \& McCarthy, J. (2006). Decentralization of Forest Administration in Indonesia: Implications for Forest Sustainability, Economic Development, and Community Livelihoods. Retrieved from http:// www.cifor.org/publications/pdf files/Books/BBarr0601.pdf

BPS. (2021). Kabupaten Ngawi Dalam Angka 2021. Ngawi: BPS Kabupaten Ngawi.

Cashore, B., Stone, M.W., 2012. Can legality verification rescue global forest governance?. Analyzing the potential of public and private policy intersection to ameliorate forest challenges in Southeast Asia. For. Policy Econ. 18, 1322. https://doi.org/10.1016/j. forpol.2011.12.005

Chambers, R. (1995). Poverty and livelihoods: Whose reality counts? Environment \& Urbanization, 7(1), 173-204. https://doi. $\mathrm{rg} / 10.1177 / 095624789500700106$

Djamhuri, T. L. (2012). The effect of incentive structure to community participation in a social forestry program on state forest land in Blora District, Indonesia. Forest Policy and Economics, 25, 1018. https://doi.org/10.1016/j. forpol.2012.02.004
Dressler, W., Büscher, B., Schoon, M., Brockington, D., Hayes, T., Kull, C. A., ... Shrestha, K. (2010). From hope to crisis and back again? A critical history of the global CBNRM narrative. Environmental Conservation, 37(1), 5-15. https://doi.org/10.1017/ S0376892910000044

Dunn, W. N. (2003). Pengantar Analisis Kebijakan Pulblik. Yogyakarta: Gadjah Mada University Press.

Edward Royce. (2018). Poverty and Power: the Problem of Structural Inequality (Third Edit). https://doi.org/10.1017/ CBO9781107415324.004

Erbaugh, J. T. (2019). Responsibilization and social forestry in Indonesia. Forest Policy and Economics, 109(August), 102019. https://doi. org/10.1016/j.forpol.2019.102019

Erbaugh, J. T., \& Nurrochmat, D. R. (2019). Paradigm shift and business as usual through policy layering: Forest-related policy change in Indonesia (1999-2016). Land Use Policy, 86(May), 136146. https://doi.org/10.1016/j. landusepol.2019.04.021

Fisher, M.R., Dhiaulhaq, A., Sahide, M.A.K., 2019. The politics, economies, and ecologies of indonesia's third generation of social forestry: An introduction to the special section. For. Soc. 3, 152-170. https://doi.org/10.24259/ fs.v3i1.6348 
Fisher, M.R., Moeliono, M., Mulyana, A., Yuliani, E.L., Kamaluddin,Adriadi, A., Judda, J., Sahide, M.A.., 2018. Assessing the New Social Forestry Project in Indonesia : Recognition , Livelihood and Conservation? Assessing the new social forestry project in Indonesia : recognition, livelihood and conservation? Int. For. Rev. 20, 346-361.

Galudra, G. (2019). Focusing on facilitation: Issues and challenges of capacity development in Indonesia'S social forestry reforms. Forest and Society, 3(1), 133-136. https://doi. org/10.24259/fs.v3i1.5995

Gelo, D., \& Koch, S. F. (2012). Does one size fit all? Heterogeneity in the valuation of community forestry programs. Ecological Economics, 74, 85-94. https://doi.org/10.1016/j. ecolecon.2011.11.010

Giessen, L., Krott, M., \& Möllmann, T. (2014). Increasing representation of states by utilitarian as compared to environmental bureaucracies in international forest and forestenvironmental policy negotiations. Forest Policy and Economics, 38, 97-104. https://doi.org/10.1016/j. forpol.2013.08.008

Gilmour, D. (2016). Forty years of community-based forestry: $A$ review of its extent and effectiveness. Rome: Food and Agriculture Organization of United Nation.

Krott, M. (2005). Forest Policy Analysis. In Forest Policy Analysis. https://doi. org/10.1007/1-4020-3485-7
Krott, M. (2008). Forest Government and Forest Governance within a Europe in change. In L. Cesaro, P. Gatto, \& D. Pettenella (Eds.), The Multifunctional Role of Forests - Policies, Methods and Case Studies (pp. 13-25). European Forest Institute.

Krott, M., \& Hasanagas, N. D. (2006). Measuring bridges between sectors: Causative evaluation of cross-sectorality. Forest Policy and Economics, 8(5), 555563. https://doi.org/10.1016/j. forpol.2005.07.004

Lo, C. (2018). Going from Government to Governance. In M. BonnafousBoucher \& Y. Pesqueux (Eds.), Global Encyclopedia of Public Administration, Public Policy, and Governance (pp. 1-5). https://doi. org/10.1057/9780230524224

Maryudi, A. (2012). Restoring State Control Over Forest Resources Through Administrative Procedures: Evidence From a Community Forestry Programme in Central Java, Indonesia. Austrian Journal of South - East Asian Studies, 5(2), 229-242. Retrieved from https:// doi.org/10.4232/10.ASEAS-5.2-3

Maryudi, A., Devkota, R. R., Schusser, C., Yufanyi, C., Salla, M., Aurenhammer, H., ... Krott, M. (2012). Back to basics: Considerations in evaluating the outcomes of community forestry. Forest Policy and Economics, 14(1), 1-5. https://doi. org/10.1016/j.forpol.2011.07.017 
Maryudi, A., \& Krott, M. (2012). Poverty Alleviation Efforts through a Community Forestry Program in Java, Indonesia. Journal of Sustainable Development, 5(2), 43-53. https://doi.org/10.5539/jsd. v5n $2 \mathrm{p} 43$

Morhart, C. D., Douglas, G. C., Dupraz, C., Graves, A. R., Nahm, M., Paris, P., ... Spiecker, H. (2014). Alley coppice-a new system with ancient roots. Annals of Forest Science, 71(5), 527-542. https://doi. org/10.1007/s13595-014-0373-5

Nurfatriani, F., Darusman, D., Nurrochmat, D. R., Yustika, A. E., \& Muttaqin, M. Z. (2015). Redesigning Indonesian forest fiscal policy to support forest conservation. Forest Policy and Economics, 61, 39-50. https://doi.org/10.1016/j. forpol.2015.07.006

Nurrochmat, D. R., Pribadi, R., Siregar, H., Justianto, A., \& Park, M. S. (2021). Transformation of AgroForest Management Policy under the Dynamic Circumstances of a Two-Decade Regional Autonomy in Indonesia. Forests, 12(4), 419. https://doi.org/10.3390/f12040419

Osborne, D. T., \& Gaebler, T. (1993). Reinventing Government: How the Entrepreneurial Spirit is Transforming the Public Sector. United Kingdom: Plume.

Ostrom, E., Janssen, M. A., \& Anderies, J. M. (2007). Going beyond panaceas. Proceedings of the National Academy of Sciences, 104(39), 15176-15178. https://doi. org/10.1073/pnas.0701886104
Peluso, N. L. (2011). Emergent forest and private land regimes in Java. Journal of Peasant Studies, 38(4), 811-836. https://doi.org/10.1080/0 3066150.2011 .608285

Prabowo, D., Maryudi, A., Imron, M. A., \& Senawi. (2016). Enhancing the application of Krott et al.'s (2014) Actor-Centred Power (ACP): The importance of understanding the effect of changes in polity for the measurement of power dynamics over time. Forest Policy and Economics, 62, 184186. https://doi.org/10.1016/j. forpol.2015.10.006

Prabowo, D., Maryudi, A., Senawi, \& Imron, M. A. (2017). Conversion of forests into oil palm plantations in West Kalimantan, Indonesia: Insights from actors' power and its dynamics. Forest Policy and Economics, 78, 32-39. https://doi. org/10.1016/j.forpol.2017.01.004

Pratama, A. A. (2019). Lessons Learned from Social Forestry Policy in Java Forest: Shaping the Way Forward for New Forest Status in exPerhutani Forest Area. Jurnal Ilmu Kehutanan, 13(2), 127. https://doi. org/10.22146/jik.52092

Pribadi, R., Nurrochmat, D. R., \& Suhendang, E. (2020). Enhancing the Role of the District Government in Decentralized Forest Management. Jurnal Manajemen Hutan Tropika (Journal of Tropical Forest Management), 26(2), 114-122. https://doi.org/10.7226/ jtfm.26.2.114 
Ragandhi, A., Hadna, A. H., Setiadi, S., Schusser, C., Krott, M., Logmani, J., \& Maryudi, A. (2021). Why do greater forest tenure rights not enthuse local communities? An early observation on the new community forestry scheme in state forests in Indonesia. Forest and Society, 5(April), 159-166. https:// doi.org/10.24259/fs.v5i1.11723

Rahayu, S., Laraswati, D., Pratama, A. A., Sahide, M. A. K., Permadi, D. B., Wibowo, W., ... Maryudi, A. (2020). Bureaucratizing nongovernment organizations as governmental forest extension services in social forestry policy in Indonesia. Forests Trees and Livelihoods, 29(2), 119-129. https://doi.org/10.1080/14728028. 2020.1753585

Ramadhan, R., Amalia, R. N., \& Wibowo, F. A. C. (2021). Dynamics Of Determining IPHPS And Kulin-Kk In The Perhutani Area (Case Study On Kth Tambak Baya And LMDH Buana Mukti In FMU Garut). Journal of Forestry Research, 4(April), 24-35.

Sahide, M. A. K., Supratman, S., Maryudi, A., Kim, Y.-S., \& Giessen, L. (2016). Decentralisation policy as recentralisation strategy: forest management units and community forestry in Indonesia. International Forestry Review, 18(1), 78-95. https://doi. $\mathrm{rg} / 10.1505 / 146554816818206168$ Sadath, N., Movuh, M. C. Y., \& Salla, M. (2013). Community Forestry in Germany, a Case Study Seen Through the Lens of the International Model. Journal of Sustainable Development, 6(9), 88-100. https://doi.org/10.5539/ jsd.v6n9p88

Setiahadi, R. (2012). Modal Sosial dalam Pembangunan Kehutanan :Penyelesaian Deforestasi dan Konflik PHBM di Kabupaten Ngawi. Universitas Gadjah Mada.

Setiahadi, R., Pratiwi, D., \& Ratnaningtyas, D. (2017). Deliberation process analysis of community based forest management policies implementation in Indonesia. International Journal on Advanced Science, Engineering and Information Technology, 7(3), 1076-1082. https://doi. org/10.18517/ijaseit.7.3.2127

Suharjito, D. (2018). Dramaturgy of agrarian reform in forestry sector in java Indonesia. IOP Conference Series: Earth and Environmental Science, 196(1). https://doi.org/10.1088/17551315/196/1/012046 
Sunderlin, W. D. (1997). An ex-post methodology for measuring poor people's participation in social forestry: An example from Java, Indonesia. Agroforestry Systems, 37(3), 297-310. https://doi. org/10.1023/A:1005977907533

Vermeulen, S., Nawir, A. A., \& Mayers, J. (2008). Rural poverty reduction through business partnerships? Examples of experience from the forestry sector. Environment, Development and Sustainability, 10(1), 1-18.https://doi. org/10.1007/s10668-006-9035-6

Wahyudi, R., \& Wicaksono, R. L. (2020). Policy forum: Village fund for REDD+ in Indonesia: Lessons learned from policy making process at subnational level. Forest Policy and Economics, 119(July), 102274. https://doi.org/10.1016/j. forpol.2020.102274

Wibowo, A., \& Giessen, L. (2015). Absolute and relative power gains among state agencies in forest-related land use politics: The Ministry of Forestry and its competitors in the REDD+ Programme and the One Map Policy in Indonesia. Land Use Policy, 49, 131141. https://doi.org/10.1016/j. landusepol.2015.07.018
Wulandari, C., Budiono, P., \& Ekayani, M. (2019). Impacts of the new Decentralization Law 23/2014 to the implementation of Community Based Forest Management in Lampung Province, Indonesia. IOP Conference Series: Earth and Environmental Science, 285(1), 012006. https://doi.org/10.1088/17551315/285/1/012006

Yokota, Y., Harada, K., Rohman, Silvi, N. O., Wiyono, Tanaka, M., \& Inoue, M. (2014). Contributions of Company-Community Forestry Partnerships (PHBM) to the Livelihoods of Participants in Java, Indonesia: A Case Study in Madiun, East Java. Japan Agricultural Research Quarterly: JARQ, 48(3), 363-377. https://doi. org/10.6090/jarq.48.363. 